\title{
Myeloblasts 5-19 Percent of Bone Marrow Nucleated Cells
}

National Cancer Institute

\section{Source}

National Cancer Institute. Myeloblasts 5-19 Percent of Bone Marrow Nucleated Cells. NCI Thesaurus. Code C36229.

A semi-quantitative microscopic finding indicating that 5-19 percent of the nucleated cells in a bone marrow sample are immature mononuclear cells of myeloid origin. 